ACTA AGROBOTANICA

Vol. 58, z. 12005

s. 5965

\title{
Research on the development of Mycosphaerella graminicola (Fuckel) Schroeter teleomorph on wheat leaves from Poland and Czech Republic
}

\section{EWA MIRZWA-MRÓZ ${ }^{1}$, LUDVIK TVARŮ•EK ${ }^{2}$, CZESŁAW ZAMORSKI ${ }^{1}$, BOGDAN NOWICKI ${ }^{1}$}

\footnotetext{
${ }^{1}$ Warsaw Agricultural University, Department of Plant Pathology, Nowoursynowska 159, 02776 Warszawa, Poland

${ }^{2}$ Agricultural Research Institute Kroměři $\bullet$ Ltd., Department of Integrated Plant Protection, Havlíčkova 2787, 76701 Kroměří, Czech Republic
}

(Received: 15.03.2005)

\section{Summary}

The aim of the work was to study the development of pseudothecia of $M$. graminicola. The experiment was carried out in 2002/2003. Wheat leaves collected at Kończewice (near Toruń), Słupia Wielka (near Poznań) and Kroměří (Czech Republic) were kept on an experimental field in Warsaw. The pseudothecia were observed under the light and transmission electron microscopy.

The first pseudothecia were observed on the dead leaves at the end of July. The largest number of fruiting bodies were noted in October.

During the whole period of observation fruiting bodies contained asci in several stages of development. Most of them were immature. In spring the pseudothecia were not found.

Key words: Mycosphaerella graminicola, pseudothecia, teleomorph

\section{INTRODUCTION}

Septoria tritici blotch caused by Mycosphaerella graminicola (Fuckel) Schroeter (anamorph: Septoria tritici Rob. ex Desm.) is one of the main wheat leaf necrotic spot diseases. The pathogen infects mainly Triticum aestivum L. and Triticum durum L. and occasionally X Triticosecale Witt., Secale cereale L. and some grass species (Weber, 1922; Williams and Jones, 1973; Brokenshire, 1975; Zamorski and Schollenberger, 1995; Zamorski et al., 1996b).

Under favourable conditions the yield losses in wheat culture range from 30 up to $50 \%$ (K e m a , 1996). The intensity of the disease depends on the cultivar susceptibility, the availability of inoculum, crop management and predisposing environmental 
conditions (S i m on and Cord o, 1998). Heavily infected leaves die prematurely (E y a 1 et al., 1987; Zamorski and Nowicki, 1997).

Until the end of 70th M. graminicola and Septoria tritici were considered to be the separate species. As late as in 1972 Sanderson connected the perfect stage M. graminicola with imperfect stage $S$. tritici (S a n der son, 1972, 1976).

So far the sexual stage (teleomorph) of M. graminicola has been identified in many countries of the world, namely Australia (B row n et al.,1978), Chile (Mad a ri a g a, 1986), USA (S a n d e r s on et al., 1986), Brazil (M e th a, 1986), United Kingdom (S cott et al., 1988), Germany (Verreet, 1995), Netherlands (Ke ma, 1996), France (Halama, 1996) and Poland (Zamorski et al., 1996a).

M. graminicola teleomorph develops on straw debris and stubble (mainly on leaf sheaths) in the form of dark-brown pseudothecia (B rown et al.,1978; Ke ma, 1996; Sanderson and Hampton, 1978; Scott et al., 1988). On the same leaf besides the pseudothecia of M. graminicola the pseudothecia of Phaeosphaeria sp. and Didymella exitialis were found very often (S a nders on, 1972; S a nders on and Hampton, 1978; Eyal et al., 1987; Halama, 1996; Zamorski et al., 1996a). Because the ascospores can be carried by the wind for many kilometres ( $\mathrm{S}$ a n derson and Hampton, 1978) it is suggested that they can be the efficient source of primary infection. (B rown et al., 1978; S anders on and Hampton, 1978; Ey al et al., 1987; S cott et al., 1988; Verret, 1995; Hala ma, 1996; S haw, 1999). The occurrence of teleomorph in Poland was reported in 1996 (Za morski et al., 1996a) but there is a lack of information concerning the development of this stage in our country.

\section{MATERIALS AND METHODS}

The experiment was carried out in 2002/2003. Wheat leaves collected at Kończewice (near Toruń), Słupia Wielka (near Poznań) and Kroměřı (Czech Republic) were kept on the experimental field in Warsaw. To determine seasonal occurrence of pseudothecia and the stage of their development samples of the leaves (from Kończewice and Słupia Wielka) were taken once a week in summer and autumn and twice a month in winter and spring. A hundred of pseudothecia, asci and ascospores have been measured to determine their size. The pseudothecia were investigated under the light (Olympus BX 50 ) and transmission electron microscope (JEOL type JEM 1220) in the Laboratory of Electron Microscopy of the Warsaw Agricultural University.

Leaves bearing fruiting bodies were cut into $5 \times 2 \mathrm{~mm}$ pieces and fixed for $2 \mathrm{~h}$ in $4 \%$ paraformaldehyde and 5\% glutaralaldehyde ( $\mathrm{pH} 7,2-7,3)$. Material was rinsed in $0,2 \mathrm{M}$ cacodylic buffer (4 x $15 \mathrm{~min}$.) and post-fixed with $2 \%$ buffered osmium tetraoxide for $2 \mathrm{~h}$. Materials were dehydrated in ethanol and acetone series and embedded in resin. Polymerisation lasted $24 \mathrm{~h}$. at $60^{\circ} \mathrm{C}$. Ultra-thin sections were cut with Diatome diamond knife by the Reichert Ultracut E Microtome, mounted on copper grids, stained for 20 min. in uranyl acetate and Reynold's citrate for 30 min. Thick sections for light microscope observations were cut by the same ultramicrotome but with glass knife and stained with methylene blue $2 \%$ and azure B $1 \%$.

On the leaves from Kroměŕ • occurrence of pseudothecia and their development were observed using light microscope only. 


\section{RESULTS}

The first pseudothecia with developed asci of $M$. graminicola were observed on the dead leaves at the end of July. The largest number of fruiting bodies were noted in October.

During the whole period of observation pseudothecia contained asci in several stages of development (asci with granulated cytoplasm without ascospores, asci with immature ascospores, asci with mature ascospores) were noted (Fig. 1-4). Most of asci was immature. The biggest percentage of asci in pseudothecia with mature ascospores was observed in September (average 18\%) and October (average 22\%) (Fig 5). The courses of air temperatures and rainfalls are represented Fig. 6.

Pseudothecia of $M$. graminicola were dark brown, globose, embedded in the host tissue with raised ostioles. Pseudothecia measured 68-99 x 70-110 $\mu \mathrm{m}$. Bitunicate, obpyriform 30-46 $\mu \mathrm{m}$ long and 10-13 $\mu \mathrm{m}$ wide asci were formed in pseudothecia. Each ascus contained eight irregularly arranged ascospores which were two-celled, hyaline and measured 11-15 x 2,2-4,4 $\mu \mathrm{m}$ (one cell was slightly longer and broader than the other). No pseudoparaphyses were present.

The empty pseudothecia, after total ascospores release were observed as well. In spring the pseudothecia on the winter wheat leaves were not found.

The development of pseudothecia of $M$. graminicola on the leaves from the Czech Republic was similar.

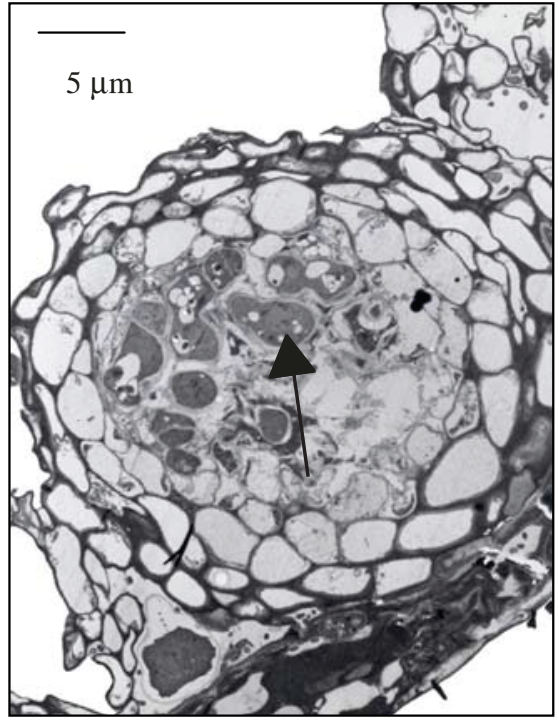

Fig. 1. The first phase of asci development

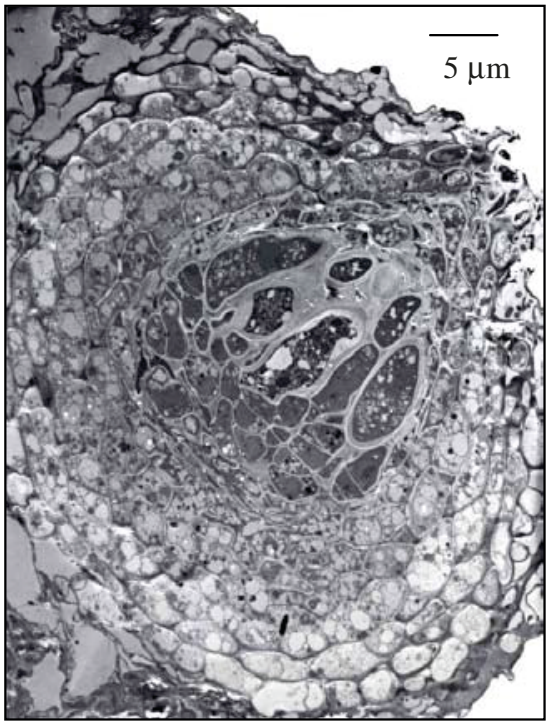

Fig. 2. Pseudothecium with immature asci with granulated cytoplasm 


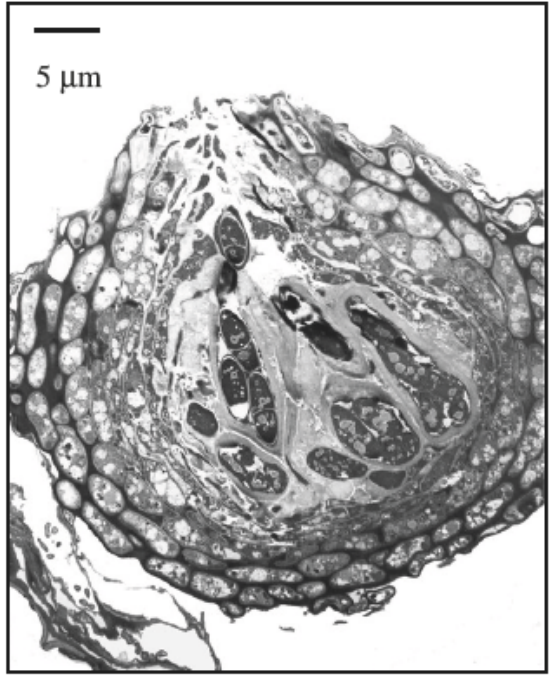

Fig. 3. Pseudothecium with asci containing single mature ascospores

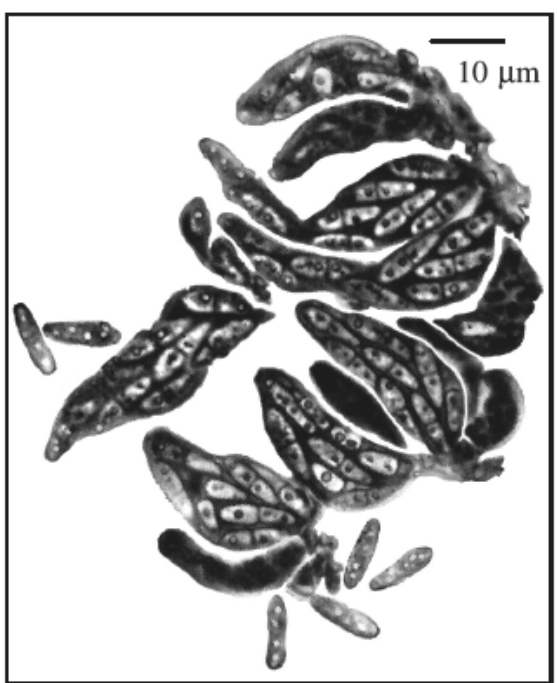

Fig. 4. Asci of M. graminicola with mature ascospores

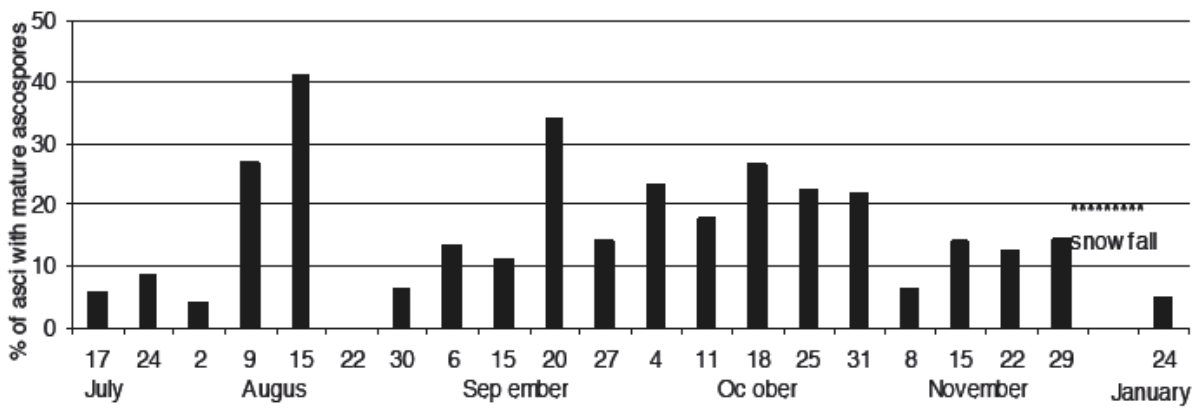

Fig. 5. Percentage of asci with mature ascospores in pseudothecia of $M$. graminicola

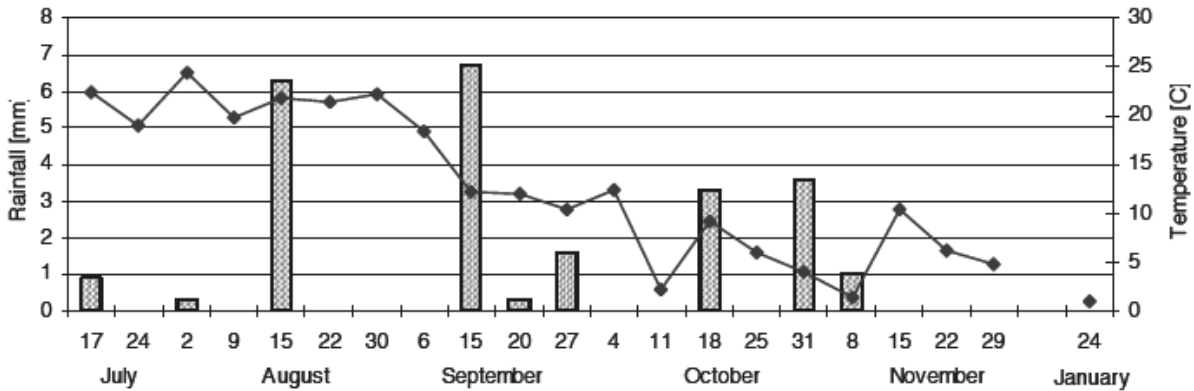

Fig. 6. Courses of air temperatures and rainfalls 


\section{DISCUSSION}

In Poland like in many countries mentioned above the occurrence of pseudothecia of M. graminicola was observed. Our investigations have shown the presence of first pseudothecia on dead winter wheat leaves before harvest already in July. In other countries pseudothecia of this fungus appeared after harvest in autumn ( $\mathrm{S}$ a n derson, 1972; Brown et al., 1978; Sanderson and Hampton, 1978; Scott et al., 1988; Hal ama 1996).

In Poland like in Australia (B rown et al., 1978) and Argentina (Cordo et al., 1999) the biggest number of pseudothecia with mature ascospores was observed in autumn (September, October), whereas in New Zealand in spring (April, May). This phenomenon can be probably explained by different weather conditions.

In France Hal a ma (1996) observed the fruiting bodies mainly on the leaves. However in United Kingdom pseudothecia were found on leaf sheaths more readily than on leaf blades possibly because the leaf sheaths decompose later than leaves blades (S c ott et al., 1988). In Poland the pseudothecia were observed on leaves like in France.

\section{REFERENCES}

Brokenshire T., 1975. The role of graminiceous species in the epidemiology of Septoria tritici on wheat. Plant Pathology 24: 3338.

Brown J. S., Kellock A. W., Paddick R. G., 1978. Distribution and dissemination of Mycosphaerella graminicola (Fuckel) Schroeter in relation to the epidemiology of spec kled leaf blotch of wheat. Aust. J. Agric. Res. 29: 11391145.

Cordo C. A., Simon M. R., Perello A. E., Alippi H. E., 1999. Spore dispersal of leaf blotch pathogens of wheat (Mycosphaerella graminicola and Septoria tritici). (in:) van Ginkel M., McNab A., Krupinsky J. (eds.). 1999. Septoria and Stagonospora diseases of cereals: A compilation of global research. Mexico, D. F.: CIMMYT, 98101.

Eyal Z., Scharen A. L., Prescott J. M., van Ginkel M., 1987. The Septoria Diseases of Wheat: Concepts and methods of disease management. Mexico D. F.: CIMMYT, p. 146.

Halama P., 1996. The occurrence of Mycosphaerella graminicola, teleomorph of Septoria tritici in France. Plant Pathology 45: 135138.

Kema G. H. J., 1996. Mycosphaerella graminicola on wheat. Genetic variation and histopa thology. Doctor thesis. Landbouwuniversiteit te Wageningen, pp. 141.

Madariaga B. R., 1986. The occurrence in Chile of Mycosphaerella graminicola (Fuckel) Schroeter, teleomorph of Septoria tritici Rob. ex Desm. Agricultura tecnica 46 (2): 209211.

Metha Y. R., 1986. Occurrence of Septoria tritici and its perfect stage in wheat. Fitopatologia Brasileira 11: 321 (in Verreet 1995).

S anders on F. R., 1972. A Mycosphaerella species as the ascogenous state of Septoria tritici Rob. ex Desm. New Zealand. J. Bot. 10: 707710.

Sanders on F. R., 1976. Mycosphaerella graminicola (Fuckel) Sanderson comb. nov., the ascogenous state of Septoria tritici Rob. ex Desm. New Zealand J. Bot. 14: 359360. 
S anders on F. R., Hampton J. G., 1978. Role of the perfect states in the epidemiology of the common Septoria diseases of wheat. N. Z. Journal of Agricultural Research 21: 277281.

Sanderson F. R., Scheren A. L., Eyal Z., King A. C., 1986. A study of genetic segre gation using single ascospore isolates of Mycosphaerella graminicola. Plant breeding Symposium DISR 1986. Agr. Soc. of New Zealand Special Publication 3: 195201 (in Verreet 1995).

Scott P. R., Sanders on F. R., Benedikz P. W., 1988. Occurrence of Mycosphaerella graminicola, teleomorph of Septoria tritici, on wheat debris in the UK. Plant Pathology 37: 285290.

Simon M. R., Cord o C. A., 1998. Diallel analysis of four resistance components to Septoria tritici in six crosses of wheat (Triticum aestivum). Plant Breeding 117: 123126.

Verreet J. A., 1995. Grundlagen des integrierten Pflanzenschutzes. Pflanzenschutz Nachrichten Bayer 48(1): 1321.

Weber G. F., 1922. Septoria diseases of cereals. Septoria diseases of wheat. Speckled Leaf blotch of wheat. Phytopathology 12: 558585.

Williams J. R., Jones D. G., 1973. Infection of grasses by Septoria nodorum and S. tritici. Trans. Br. Mycol. Soc. 60(2): 355358.

Zamorski C., Nowicki B., 1997. Remarks on occurrence of septoria tritici blotch (Myco sphaerella graminicola) on winter wheat in Poland. Biul. IHAR. 204: 267275.

Zamorski C., Nowicki B., Mirzwa Mróz E., 1996a. Teleomorph of Mycosphaerella graminicola (Fuckel) Schroeter in Poland. Materiały z sympozjum naukowego: „Cho roby roślin a środowisko". Poznań, 2728 June, p. 239243.

Zamorski C., Schollenberger M., 1995. The occurrence of triticale diseases in Poland. Biul. IHAR. 195/196: 197207.

Zamorski C., Schollenberger M., Nowicki B., 1996b. Diagnosis of winter wheat and triticale diseases in seedling and tillering stages. Materiały z Sympozjum „Nowe kierunki w fitopatologii”. Kraków 1113 September, p. 369372.

\section{Badania rozwoju teleomorfy grzyba Mycosphaerella graminicola (Fuckel) Schroeter na liściach pszenicy z Polski i Czech}

\section{Streszczenie}

Celem pracy były badania nad rozwojem pseudotecjów grzyba Mycosphaerella graminicola. Obserwacje prowadzono przez cały sezon wegetacyjny w latach 2002/ 2003 na polu doświadczalnym w Warszawie (Ursynów, SGGW).

Materiałem roślinnym były martwe, porażone przez patogena liście pszenicy ozimej pochodzące z ZD IHAR Kończewice (woj. kujawsko-pomorskie), Stacji Hodowli Roślin w Słupi Wielkiej (woj. wielkopolskie) i z Agricultural Research Institute Kroměří Ltd. (Czechy). Liście były przechowywane na specjalnej konstrukcji, wykonanej z drewnianej ramy, na której umocowano gęstą, plastikową siatkę. Wykładano na nią liście z objawami septoriozy paskowanej liści pszenicy i otoczniami grzyba M. graminicola, następnie przykrywano drugą siatką. 
Przebieg rozwoju otoczni ustalano na podstawie okresowych obserwacji makro- i mikroskopowych (raz w tygodniu latem i jesienią oraz 2 razy w miesiącu zimą i wiosną). Celem ich było określenie czasu pojawiania się kolejnych struktur grzyba, tj. ukształtowanych pseudotecjów, worków i zarodników workowych. Sporządzono dokumentację fotograficzną ilustrującą poszczególne etapy rozwoju otoczni grzyba M. graminicola z użyciem mikroskopu świetlnego i transmisyjnego.

Pierwsze pseudotecja grzyba obserwowano na obumarłych liściach pod koniec lipca. Największą liczbę otoczni notowano w październiku. W ciągu całego okresu obserwacji pseudotecja zawierały worki w różnych stadiach swego rozwoju. Większość z nich była niedojrzała. Wiosną pseudotecja patogena nie były już znajdowane. 
